\title{
SKIPPERS AND BUTTERFLIES OF KANANASKIS PARK, ALBERTA
}

JORBERT G. KONDLA, Parks Division, Alberta Recreation, Parks \& Wildlife, dmonton, Alberta, and CHARLES D. BIRD, Department of Biology, University f Calgary, Calgary, Alberta.

Situated in the front ranges of the Rocky Mountains, approximately 70 ilometres southwest of Calgary, Kananaskis Provincial Park is the nost recent addition to the parks ystem and was established by an prder-in-Council in the fall of 1977. Much of the current park area of 50,308 ha has been investigated from a natural resource viewpoint as part of the planning and development process. Figure 1 shows the area for which extensive resource information (including butterflies and -kippers) is available. This paper pssentially deals with the white area ather than the total existing park.

The park is a high elevation enironment for butterflies; the lowest oint being $1,604 \mathrm{~m}$ along the ananaskis River near the conuence with King Creek while the ighest point is $3,344 \mathrm{~m}$ on Mt. Sir pouglas. The mountain ranges run in northwest-southeast direction and enerally have summit elevations etween $2,432 \mathrm{~m}$ and $3,040 \mathrm{~m}$ while he intervening valleys have floor levations between $1,672 \mathrm{~m}$ and ,976 m.

Much of the park has slopes in exess of $30 \%$ and most of the typical ordilleran landforms including irques, hanging valleys, talus lopes, sheer rock faces, and alluvial ans as well as a variety of ice conact and glacio-fluvial deposits that late from the Wisconsin glaciation. he bedrock of the western portion is redominantly limestone and dolomite while sandstone and shale is more prevalent in the eastern portion.

Limited climatic data indicates that the park is situated in a relatively cool and moist portion of the front ranges. In consequence the vegetation consists largely of cool, moist spruce-fir forest of the subalpine zone. These forests are opened at irregular intervals by snow avalanches, creating linear patches of young trees, shrubland or meadows; depending on slope, aspect, elevation, and avalanche frequency. Much of this zone is covered by fire-successional lodgepole pine forests. Landslides and bedrock outcrops also provide breaks in the subalpine forest.

Depending on slope exposure, the climatic forestline occurs roughly from 2,098 $\mathrm{m}$ to $2,219 \mathrm{~m}$. Above this altitude, forest gives way to isolated clumps of trees, then isolated and depauperate trees, and finally the alpine zone with treeless vegetation consisting of meadows, heaths, and rocklands. Major variation in plant communities is dramatic over short distances due to wind, snow, and microtopography. Increasing altitude leads to open vegetation dominated by rock-dwelling lichens and cushion-forming plants until bare rock, permanent snowbanks, and glaciers comprise the environment.

An interesting aspect of Kananaskis Park is the abundance of wetlands resulting from beaver ac- 


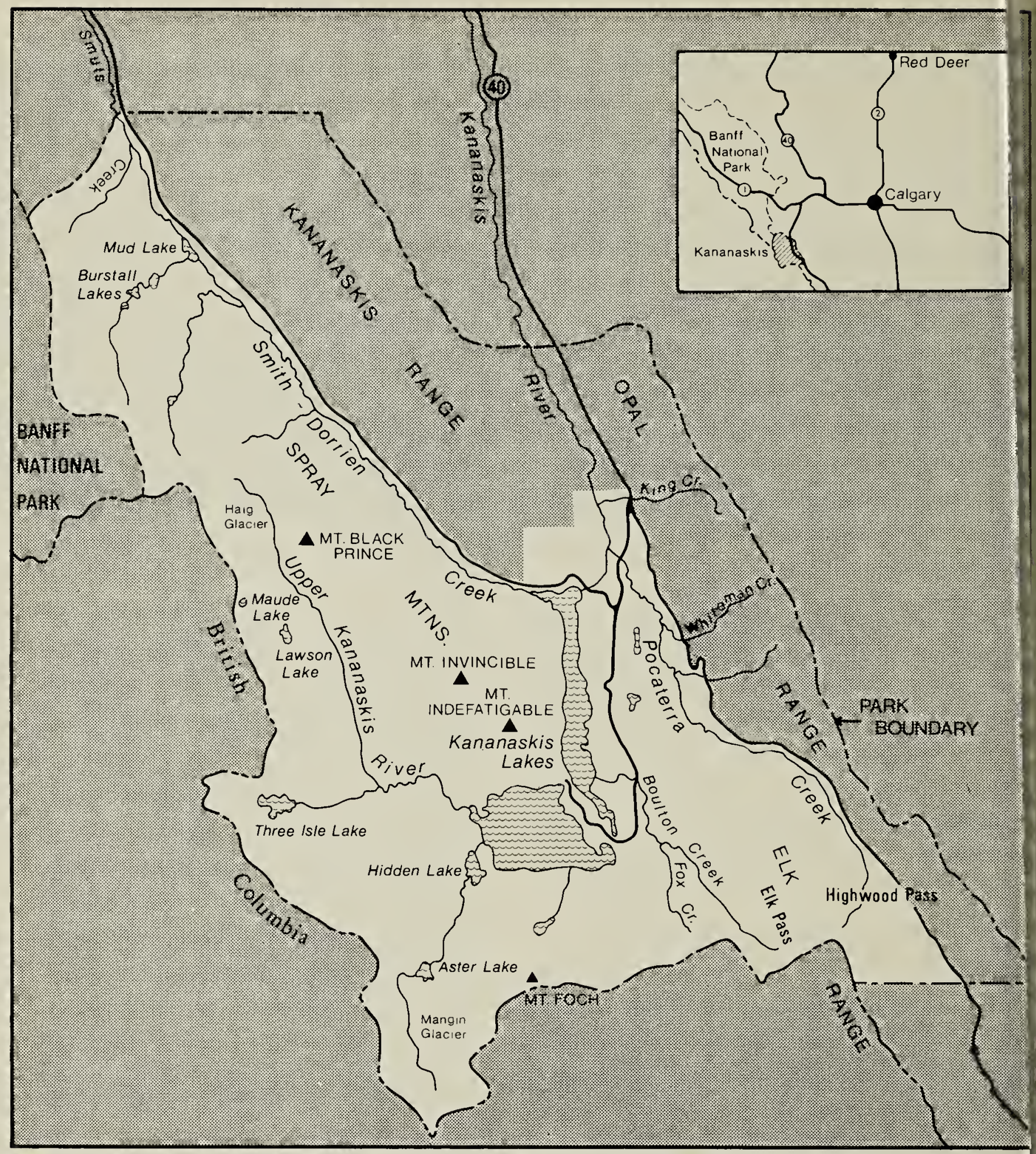

1 Figure 1 Kananaskis Provincial Park place names used in this paper.

Roughly one third of the study area consists of glaciers, permanent

snow banks, rock barrens and water; habitat unsuited for butterflies.

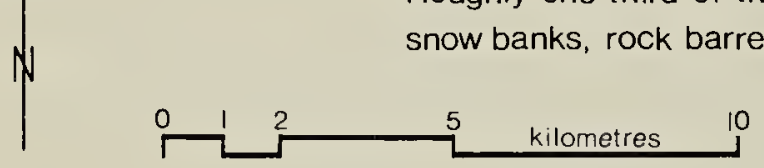

tivity and groundwater discharge in the more gently sloping portions of the valleys. These generally linear wetlands support spruce and pine bogs, tall shrub fens, low shrub fens with willows and bog birch, and sedge fens.

Montane habitats are represented in the park by two stands of Dougla fir forest - along the King Cree gorge and on the lower south slop of Mt. Indefatigable. Meadows an dry grasslands at the lowe elevations are restricted to smal areas, usually on steep south anc west facing slopes. 
Major sources of information on e natural resources of the park are ovided by Bird5, Jaques 10 ondla12, Milus Tress Barron ${ }^{14}$, regrine Research and Documention $^{16}$, and Trottier21. Figures 2 to 5 ustrate major butterfly habitats.

\section{formation Base}

The first collections were made by B. Sanson in 1922. No other bllections are known until 1955 hen R. Coyles and J. R. McGillis bllected at Highwood Pass. Subquently the Highwood Pass has pen collected by R. L. Anderson in 958, 1959, 1960, and 1961; J. Legge 1961,1962 , and $1971 ; \mathrm{S}$. higematsu in 1968, 1971, and 1972; D. Bird in 1975; H. Pinel in 1975 dd 1976; A. Wisely in 1976; and N. ondla and M. R. Lein in 1977. Other eas of the park have had minor bllections by R. L. Anderson, A. I. W. acKenzie, S. Shigematsu, A. D. ird, and C. D. Bird. Major collecons from other areas of the park ave been made by $A$. Wiseley in 976 during a wildlife inventory for e Parks Division and by N. Kondla uring a reconnaissance vegetation irvey in 1977, also for the Parks ivision. Previous reports on butteres of this area are an annotated list Bird5 and an annotated list of iseley's collections and obserations ${ }^{16 .}$.

Thus, this paper is based on bllections by 13 people, in 13 difrent years. All records except the lourning Cloak are supported by bucher specimens examined by ther of the present writers. Records fe available from the beginning of e flight season in late May to the hd of September.
PECK'S SKIPPER (Polites coras): Known from one collection by Shigematsu at Highwood Pass on 7 July 1968.

DRACO SKIPPER (Polites draco): This insect was found to be abundant in a meadow east of the Lower Kananaskis Lake by Kondla on 25 June and 21 July 1977.

MANITOBA SKIPPER (Hesperia comma manitoba): Apparently uncommon and local; known from a few collections by Anderson and Shigematsu at Highwood Pass and by Wiseley near the east side of Lower Kananaskis Lake. This species appears to prefer open, grass-rich habitats and is therefore most likely to be seen at higher elevations in the alpine and upper subalpine zone. Flight records 7 July to 9 August.

ARCTIC SKIPPER (Carterocephalos palaemon mandan): Known from a 7 August 1972 collection by Shigematsu and a 24 July collection by Lein at Highwood Pass and a collection by Kondla on 9 June at King Creek fan. Occasional sight records in clearings at lower elevations during 1977.

PERSIUS DUSKY WING (Erynnis persius): Specimens collected at Highwood Pass (Shigematsu); King Creek fan (Wiseley and Kondla), and the lower Boulton Creek area (Kondla). Seen regularly on dry open hillsides at lower elevations. Flight records 9 June to 11 July.

\section{PAPILIONIDAE - Swallowtails}

CLOUDED PARNASSIAN (Parnassius phoebus smintheus): Strangely unreported prior to 1976 despite the many collections in suitable habitat of the Highwood Pass. Reported by Wiseley from a number of locations in 1976 but Kondla found it at only one alpine location just west of Mt. Indefatigable in 1977 despite visits to apparently suitable habitat under ideal weather conditions. Flight records 16 July to 26 September.

GOTHIC SWALLOWTAIL (Papilio zelicaon gothica): Known from one collection by Wiseley on 15 July $1976 \mathrm{NE}$ of the Lower Kananaskis Lake.

PIERIDAE - Whites, Sulphurs and
Marbles

\section{Annotated List}

HESPERIIDAE - Skippers 


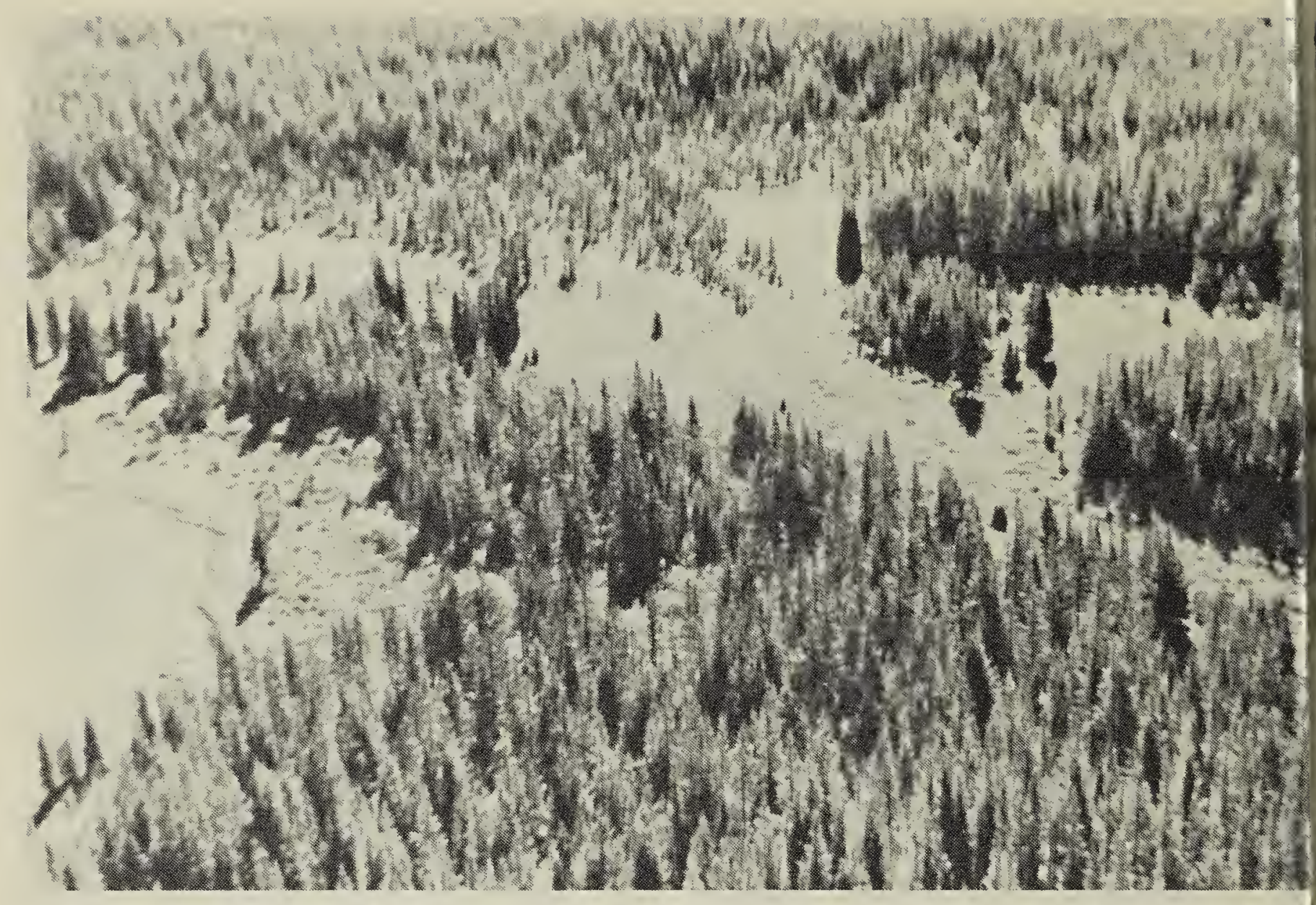

Figure 2: Aerial view of conifer bog habitat for Jutta Arctic, birch-willow fen habitat Frigga Fritillary, and lodgepole pine habitat for Purple Lesser Fritillary in the Kananas valley.

CALIFORNIA WHITE (Pieris sisymbrii flavitincta): Two fresh females were collected by Kondla on 9 June 1977 at l'ing Creek fan and King Creek gorge. Since previous investigators have not been in the field so early, the species may be more abundant here than these records indicate.

WESTERN CHECKERED WHITE (Pieris protodice occidentalis): Reported by Coyles, McGillis, Bird and Lein at Highwood Pass. Also reported by Wiseley near the Lower Kananaskis Lake and Kondla at the Upper Kananaskis Lake. Flight records 24 July to 6 September.

MUSTARD WHITE (Pieris napi): Found near Fox Creek by Wiseley and at several locations east of Lower Kananaskis Lake by Kondla. Flight records 9 June to 21 July.

CABBAGE BUTTERFLY (Pieris rapae): This introduced species was found by Kondla in a willow/sedge fen at East Elk Pass on 7 August 1977 and along the weedy edge of Upper Kananaskis Lake on 23 August 1977.
ORANGE ALFALFA BUTTERFLY (Coli eurytheme eurytheme): Known only fro one fresh male caught by Kondla 25 Jur 1977 on King Creek fan. Apparently stray migrant since the species is $n$ known to overwinter in Alberta.

ELIS SULPHUR (Colias meadii elis Collected at Highwood Pass by Coyle Anderson, Legge, Shigematsu, Bir Wiseley, Lein and Kondla. Also found Mt. Invincible and SE of Lowe Kananaskis Lake by Wiseley as well as c Mt. Indefatigable by Kondla. Apparently fairly common species of alpine an subalpine meadows. Flight records $8 \mathrm{Ju}$ to 6 September.

YELLOW ALFALFA BUTTERFLY (Colic philodice eriphyle): A few scattere collections by McGillis, MacKenzie an Wiseley. Flight records 7 July to 2 August.

PINK-EDGED SULPHUR (Colias interic interior): Lein collected 2 fresh males o 24 July 1977 at Highwood Pass.

ALEXANDRA SULPHUR (Colias alexan dra christina): No known records prior t 


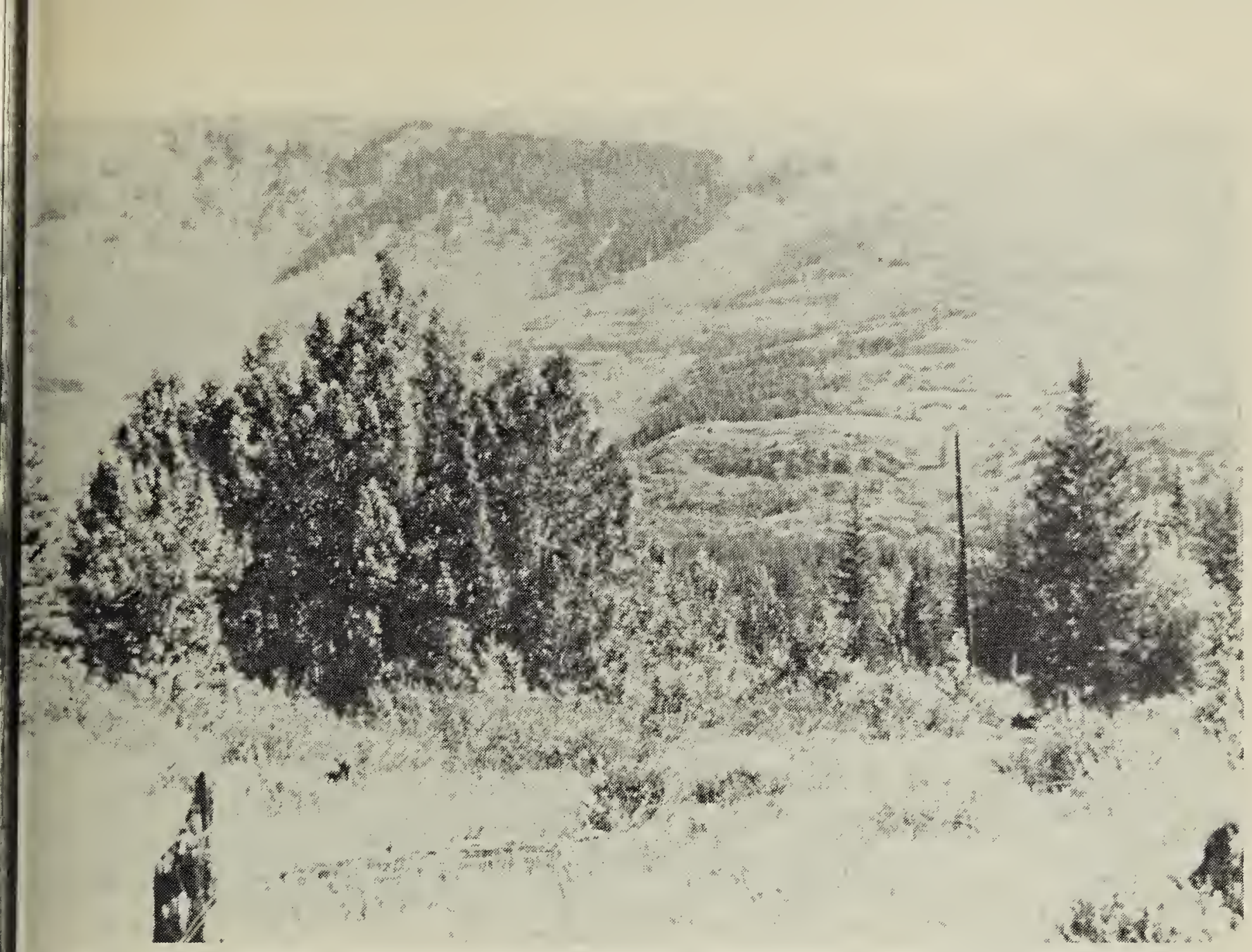

igure 3: South half of King Creek fan. Great diversity of habitats at a relatively low levation makes this one of the most productive areas for butterflies. Some species to e found here are Colorado Orange-tip, Gillett's Checkerspot, and Freija Fritillary.

976. Collected by Wiseley and by Kondla a few lower locations east of the lakes. light records 25 June to 26 September.

ELIDNE SULPHUR (Colias pelidne inisni Bean): Numerous records from ighwood Pass by Coyles, Anderson, higematsu, Legge, and Bird. Also found n Mt. Indefatigable by Kondla. An alpine nd upper subalpine zone species. Flight cords 20 July to 6 September.

IASTES SULPHUR (Colias nastes treckeri): Many records from Highwood ass by Coyles, Anderson, Shigematsu, inel, Wiseley and Lein. A ubiquitous pecies of alpine meadows. Found on Mt. ndefatigable by Kondla. Flight records 22 uly to 29 August.

YOLORADO ORANGE-TIP (Anthocaris ara julia): Not reported until 1976 when Wiseley found it at King Creek fan, Fox Freek, and lower Boulton Creek. A outhern species of montane habitats pear the northern limit of its range here. Also found in 1977 by Kondla at King Freek fan. Flight records 9 June to 17 July.

une, 1979. 37(2)
CREUSA MARBLE (Euchloe creusa): Reported from Highwood Pass by Anderson, Pinel, Wiseley and Lein. Also located by Wiseley at Fox Creek and by Kondla at King Creek fan and Boulton Creek fan. Flight records 14 June to 24 July.

\section{LYCAENIDAE - Gossamer-winged Butterflies}

MARIPOSA COPPER (Lycaena mariposa mariposa): Not reported until 1976 when Wiseley found it one mile SE of Lower Kananaskis Lake. Also found in wetlands and clearings in 1977 by Kondla. Flight records 17 July to 22 August.

ARETHUSA COPPER (Lycaena phlaeas arethusa): So far known only from one colléction by Anderson on 9 August 1958 at Highwood Pass.

SNOW'S COPPER (Lycaena snowi snowi): First found by Sanson in Upper Kananaskis Pass in 19224. Subsequently reported by Shigematsu and Lein for Highwood Pass and Kondla in an alpine area just west of Mt. Indefatigable. Flight records 24 July to 11 August. 


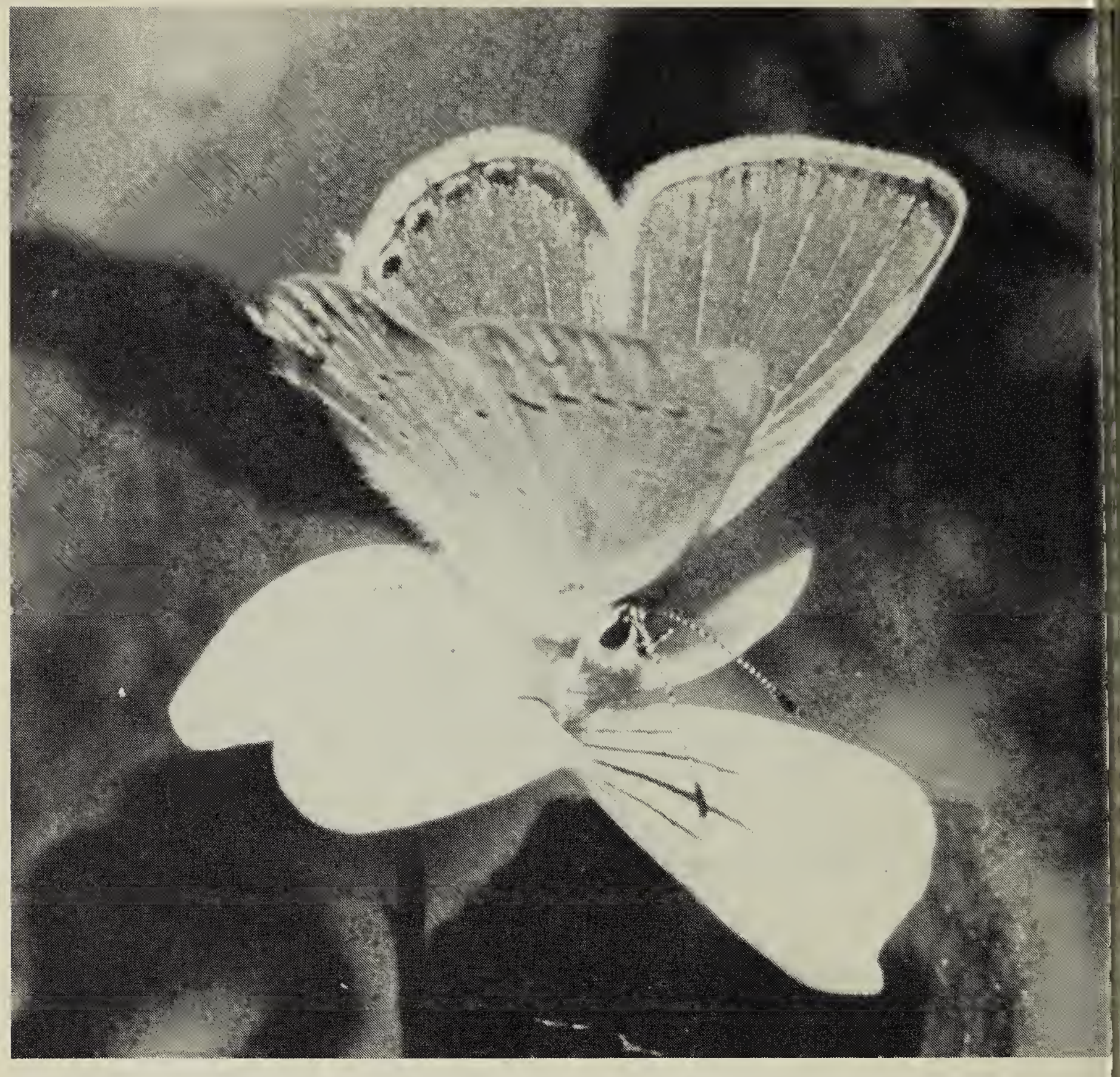

SCUDDER'S BLUE (Lycaeides argyrognomon scudderii): Reported by Anderson, Kondla, Shigematsu, and Wiseley from Highwood Pass, west of Mt. Indefatigable, lower Smith-Dorrien valley and numerous locations in the Kananaskis valley east of the lakes. Most abundant in open, dry areas at lower elevations. Flight records 22 July to 2 September.

GREENISH BLUE (Plebejus saepiolus amica): Known from collections by MacKenzie, Wiseley, and Kondla east of the lakes and by Kondla in an alpine area at Lawson Lake. Flight records 14 June to 18 August.

ACMON BLUE (Plebejus acmon lutzi): The only record so far is one fresh male taken by Kondla on 22 July 1977 in an open pine bog near Whiteman Creek.
ARCTIC BLUE (Plebejus aquilo megald Found at Highwood Pass by Anderso Coyles, Kondla and Lein. Also recorde by Kondla and by Wiseley east of th lakes and by Kondla west of $\mathrm{Mt}$. II defatigable and Elk Pass. Fairly commo in the lower alpine and upper subalpin zones although it is present in even th lowest areas of the park. Flight records 2 July to 31 August.

WESTERN TAILED BLUE (Everes amyr tula albrighti): Collected by Shigemats and Lein at Highwood Pass and Wisele on the north side of the Upper Kananaski Lake. Flight records 4 July to 24 July.

SILVERY BLUE (Glaucopsyche lygdamu. couperi): Reported from Highwood Pas by MacKenzie, Pinel, and Shigematsu Taken at a number of localities east of the lakes by Kondla and by Wiseley as well a: 
Wiseley in the Elk Pass and by Kondla Mt. Indefatigable. Most often seen in y clearings at lower elevations. Flight cords 30 May to 31 July.

\section{IYMPHALIDAE — Brush-footed Butterflies}

ED ADMIRAL (Vanessa atalanta rubria): nly record to date is one worn specimen Kondla in a large meadow east of the ower Kananaskis Lake on 25 June 1977.

IILBERT'S TORTOISE-SHELL ( $\mathrm{Nym}$ halis milberti furcillata): Found in almost I habitats by Coyles, Bird, Anderson, Viseley, Kondla, and Lein at Highwood ass, Mt. Invincible, Mud Lake, Smithorrien valley, King Creek fan, and east of pe lakes. Flight records 23 May to 25 Sepmber.

1OURNING CLOAK (Nymphalis antiopa ntiopa): The only report is a sight record y Kondla on 7 June 1977 on King Creek an.

ATYR ANGLE-WING (Polygonia satyrus atyrus): Only two records; Wiseley found pis species on the east side of Lower ananaskis Lake on 31 August 1976 and ondla found it in subalpine forest near Maude Lake on 10 August 1977.

EPHYR ANGLE-WING (Polygonia ephyrus): Found by Bird at Highwood ass on 6 September 1975 and by Kondla fom 23 May to 10 June 1977 at upper mith-Dorrien valley, King Creek gorge, ind Upper Kananaskis Lake.

AAMOETAS CHECKERSPOT (Chlosyne (amoetas): This local and rare species as so far only been found by Shigematsu t Highwood Pass on 21 July 1971.

ROCKY MOUNTAIN CHECKERSPOT Chlosyne palla calydon): Only two ecords available. Anderson found it 26 uly 1959 at Highwood Pass and MacKenie found it at the lakes on 6 July 1963.

PEARL CRESCENT (Phyciodes tharos haros): The only known occurrence omes from a report by Wiseley, 1 July 976 at Fox Creek.

MEADOW CRESCENT (Phyciodes campestris campestris): Collected at Highwood Pass by Shigematsu and Lein. Found at numerous places east of the lakes by A. D. Bird, Shigematsu, Wiseley, and Kondla. Also recorded west of Mt. Indefatigable and upper Smuts Creek by Kondla. Flight records 25 June to 19 August.

ANICIA CHECKERSPOT (Euphydryas anicia anicia): Reported by MacKenzie, Shigematsu, Pinel, and Kondla at Highwood Pass. Also found at a number of sites east of the lakes by Wiseley and by Kondla. Flight records 25 June to 18 August.

BEAN'S CHECKERSPOT (Euphydryas editha beani): This alpine species has only been reported from Highwood Pass by Pinel on 24 July 1976.

GILLETT'S CHECKERSPOT (Euphydryas gilletti): Relatively few records of this local species are available. It has been found at Highwood Pass by Legge and at a few locations east of the lakes by Mackenzie, Wiseley, and Kondla. Flight records 25 June to 22 July.

SILVER-BORDERED FRITILLARY (Boloria selene): Reported from three locations east of the lakes by Wiseley and by Kondla. Apparently a species of low shrub fens in this area. Flight records 17 July to 21 August. The Alberta populations of this species have been most frequently referred to the subspecies atrocostalis 18 but Kohler ${ }^{11}$ presents information to indicate that Alberta material represents a wide band of intergradation between the subspecies tollandensis and atrocostalis.

MEADOW FRITILLARY (Boloria bellona jenistai): Reported by MacKenzie on 6 July 1963 east of the lakes.

FRIGGA FRITILLARY (Boloria frigga saga): Found by MacKenzie and by Kondla in wetlands east of the lake. Very abundant in low shrub fens dominated by bog birch. Flight records 9 June to 6 July. FREIJA FRITILLARY (Boloria freija freija): This early flying species was found by Kondla in most open habitats at King Creek fan on 9 June 1977.

PURPLE LESSER FRITILLARY (Boloria titania grandis): Specimen and sight records too numerous to detail. Present abundantly in almost all forested portions of the park. Flight records 15 July to 29 August. 


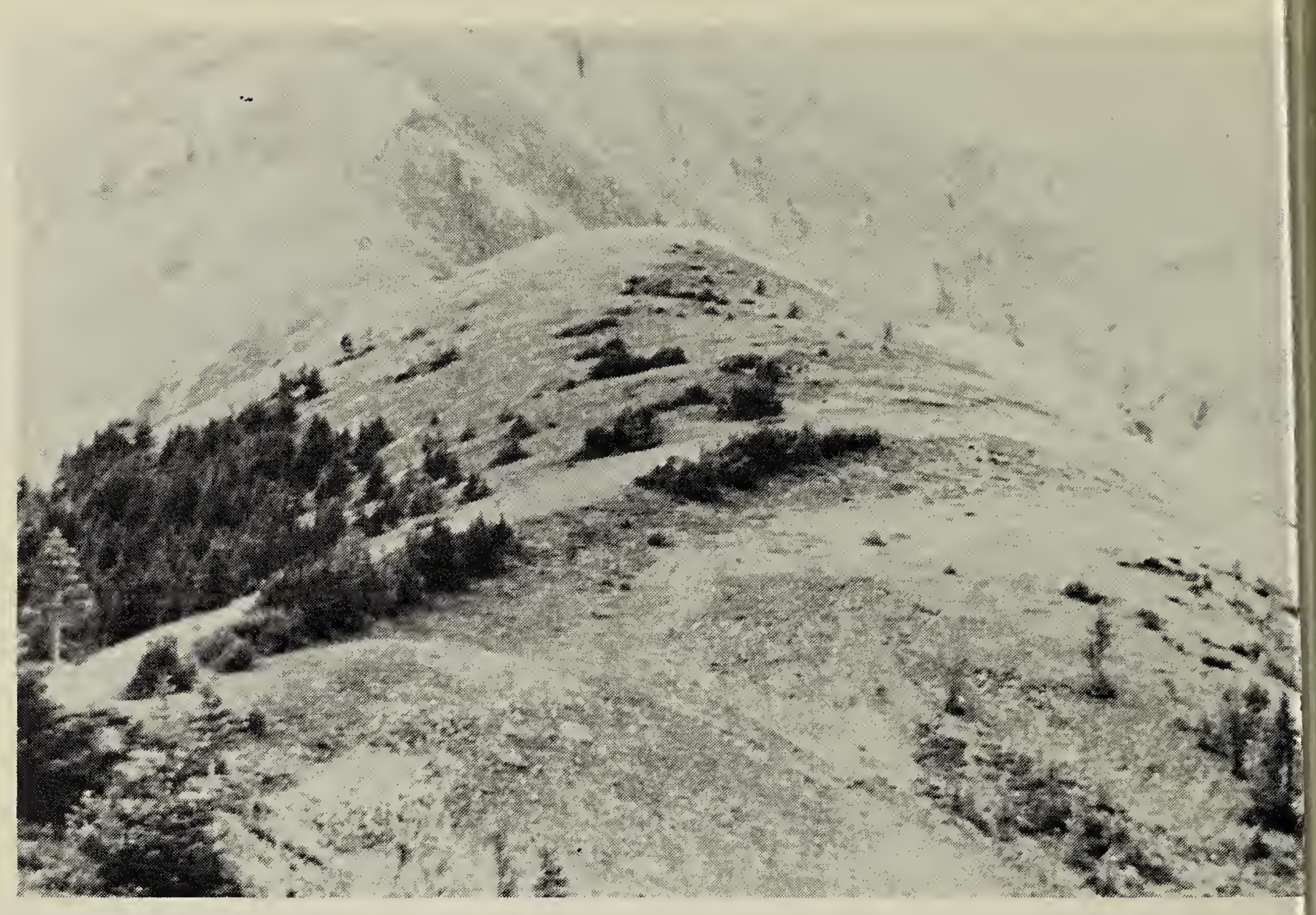

Figure 4: Barren rock cliffs above ridge with alpine and upper subalpine habitats. Ridg is habitat for such species as Clouded Parnassian, Nastes Sulphur, Snow's Copper, ar Arctic Blue.

EDWARD'S FRITILLARY (Speyeria edwardsii): Only known from one specimen by MacKenzie on 6 July 1963 east of the lakes.

ZERENE FRITILLARY (Speyeria zerene garretti): Shigematsu found one at Highwood Pass on 7 July 1968.

BEANS'S FRITILLARY (Speyeria atlantis beani): Found at many lower elevation sites in the Kananaskis valley by McKenzie, Shigematsu, Wiseley, and Kondla. Flight records 25 June to 31 August.

HYDASPE FRITILLARY (Speyeria hydaspe sakuntala): This distinctive fritillary was discovered by Kondla on 5 August 1977 north west of the Upper Kananaskis Lake and at King Creek fan on 19 August 1977.

MORMONIA FRITILLARY (Speyeria mormonia eurynome): Reported by Sanson, MacKenzie, Pinel, Wiseley, and Kondla from most parts of the park up to timberline. Flight records 15 July to 22 August.

VARIEGATED FRITILLARY (Euptoieta claudia): One report by MacKenzie on July 1963 near the lakes.

\section{SATYRIDAE - Meadow Browns}

SMALL WOOD NYMPH (Cercyonis oetu. charon): Reported by Anderson for High wood Pass on 9 August 1958 and Kondl on 19 August on King Creek fan.

MACOUN'S ARCTIC (Oenei macounii) Reported by MacKenzie on 6 July 196: east of the Lower Kananaskis Lake.

CHRYXUS ARCTIC (Oeneis chryxu. chryxus): Found at Highwood Pass b Coyles, Wiseley, Kondla and Lein as wel as at a number of sites in the Kananaski: valley by MacKenzie, Wiseley, anc Kondla. Flight records 14 June to August.

JUTTA ARCTIC (Oeneis jutta chermocki): This very dark subspecies was located by Kondla in fens and bogs of the area east of the Lower Kananaskis Lake. Most frequently seen in open pine and spruce bog margins of the linear wetlands. Flight records 9 June to 22 July. 
BEAN'S ARCTIC (Oeneis melissa beani): Only found by Pinel at Highwood Pass on 24 July 1976.

BRUCE'S ARCTIC (Oeneis polixenes brucei): The only report so far is by Wiseley at Highwood Pass on 8 July 1976.

COMMON ALPINE (Erebia epipsodea epipsodea): Reported from Highwood Pass by Coyles, Pinel, Wiseley, and Lein. Found at a number of locations in the Kananaskis valley by Wiseley and by Kondla. Flight records 14 June to 9 August.

\section{Discussion}

As reported in the annotated list, the known Rhopaloceran fauna of the park consists of 59 species in 6 of the 7 families reported for Alberta. In terms of the number of species per family, the Alberta fauna is representative of the ranking of families for Canada and the U.S.A. The only difference is that in the continental fauna the Lycaenidae contains more species than the Nymphalidae.

As shown in Table 1, the situation in the park is substantially different. In the park fauna, the families Pieridae, Nymphalidae, and Satyridae form a significantly larger portion of the fauna than they do in the provincial fauna. In contrast, the Hesperiidae and Lycaenidae are proportionally less represented in the park fauna.

A preliminary analysis of reported butterfly faunas of mountain areas in western North Americal 2671520 shows a consistently greater percentage of Nymphalidae and a lesser percentage of Hesperiidae and Lycaenidae in the more northerly mountain areas as compared with the more southerly areas.

Table 2 compares the elevation and butterfly phenology of the park with Banff National Park2, Plateau Mountain1, and Calgary ${ }^{3}$. The data show a clear and dramatic short- ening of the flight period as well as a pronounced seasonal shift in the peak flight period in relation to increasing altitude. The peak number of species decreases noticeably with increasing altitude when the three mountain areas are compared but there is no significant difference between Banff and Calgary. The peak Calgary flight period is substantially earlier than the mountain areas.

These differences may be attributed to the greater climatic, habitat, and faunal differences between Calgary and mountain areas. In contrast, Kananaskis butterfly phenology parameters are consistently intermediate in comparison to Banff and Plateau Mountain; a situation that is expected due to the intermediate environmental and geographic position of Kananaskis.

The absence of certain species is as interesting as is the presence of others. For example, a number of widespread and generally abundant species have not been reported in the park. These include the Tiger Swallowtail (Papilio glaucus), Spring Azure (Celastrina argiolus), White Admiral (Limenitis arthemis), Hoary Elfin (Callophrys polios), Brown Elfin (Callophrys augustinus), Western Pine Elfin (Callophrys eryphon), Ringlet (Coenonympha tullia), and Dreamy Dusky Wing (Erynnis icelus). Sufficient field research was undertaken by Kondla at suitable times and habitats to indicate that these species must be very local if they are indeed present in the park.

The absence of the Tiger Swallowtail, Spring Azure, White Admiral, and Dreamy Dusky Wing can be explained by the effective absence of poplar forest habitat with its associated larval food plants. Poplars are present only in scattered small stands and isolated trees. Similarly the lack of grasslands, 


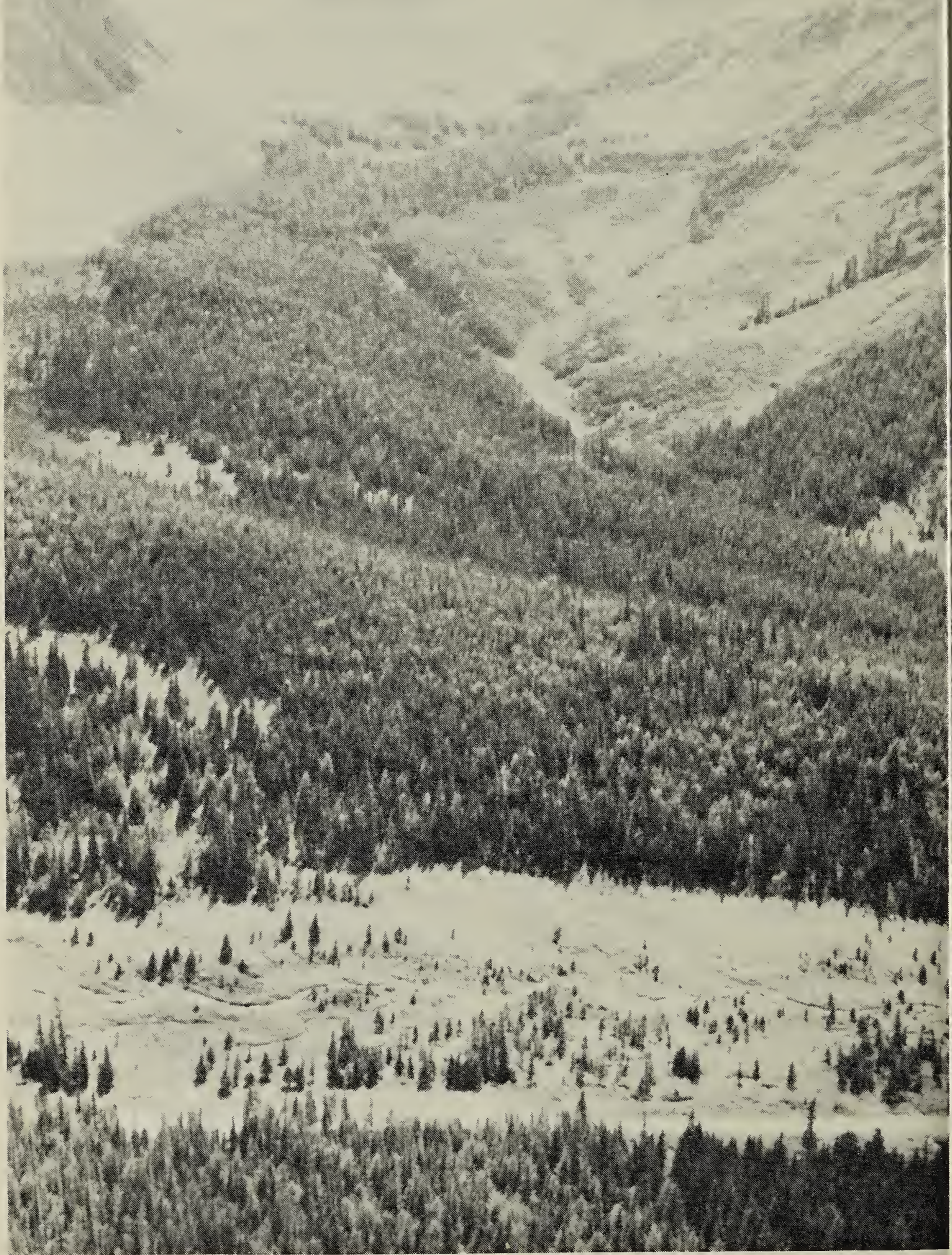

Figure 5: View from the east cirque of Highwood Pass. Alpine meadows, willow thickets avalanched alpine fir, and spruce-alpine-fir larch forests provide a variety of butterfly habitats. Typical species of this area are Chryxus Arctic, Milbert's Tortoise-shell, Pelidne Sulphur, and Elis Sulphur. 
TABLE 1: Comparison of Kananaskis Provincial Park and total provincial Rhopaloceran fauna.

FAMILY

PARK

PROVINCE

Hesperiidae

Papilionidae

Pieridae

Lycaenidae

Nymphalidae

Dandaidae

Satyridae

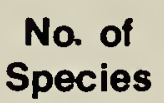 \\ No. of
Species}

5

2

13

9

23

0

7

\section{Percent \\ of Fauna}

$8 \%$

$3 \%$

$22 \%$

$15 \%$

$39 \%$

0

$12 \%$
No. of

Species

27

8

19

36

46

1

15
Percent of Fauna

$17 \%$

$5 \%$

$13 \%$

$24 \%$

$30 \%$

$0.6 \%$

$10 \%$ other than isolated patches, can be used to explain the absence of Ringlets.

The elfins represent a more difficult problem. Apparently suitable patches of bearberry (Arctostaphylos uva-ursi) are widespread in the lower elevation lodgepole pine forests and should theoretically support Hoary Elfins and Brown Elfins. Caterpillars of the Western Pine Elfin have a limitless food supply in the large forests of lodgepole pine. Although admittedly conjectural, the absence of these species may be attributed to climate. The climatic climax forests of the areas currently occupied by lodgepole pine, are spruce-fir forests which are indicative of cool, moist conditions. Similarly the predominant understory plant of the pine forest is grouseberry ( $\mathrm{Vac}$ cinium scoparium) - a plant usually associated with high elevations and indicative of cool, moist conditions.

Available information, although unbalanced, indicates greater variety and abundance of alpine butterflies on the shales of the Highwood Pass when compared with the limestones and dolomites that predominate in the more westerly portions of the park. However, this trend is supported by observations elsewhere in the mountains of Alberta.
The park has a relatively poor representation of the arctic-alpine tundra butterfly fauna recently studied by Pike17. This may be merely an artifact of the amount of research which has been conducted in the alpine zone. However, when one considers the amount and distribution of alpine tundra in the park, this may be a real situation. At best, the alpine tundra butterfly fauna of the park will be local in the small patches of such habitat which is available. Excessively steep slopes prevent establishment of rich alpine tundra. vegetation which is required by some species and also severely constrains research. The highly calcareous bedrock which predominates in the park is not conducive to good growths of dark lichens and other plants which are a characteristic feature of fellfields that support good populations of species such as Boloria alberta, Oeneis melissa, and Euphydryas editha.

A large volume of recent research has shown that many ecosystems are dependent on or subject to relatively frequent fires. This is certainly true for the mountains of southwestern Alberta9 13 19. Butterflies are essentially herbivorous insects and insofar as fire determines the distribution of food plants in space and time, fire 
TABLE 2: Butterfly phenology and elevations of four Alberta Areas.

$\begin{array}{lccll}\text { AREA } & \begin{array}{c}\text { Flight } \\ \text { Period } \\ \text { (days) }\end{array} & \begin{array}{c}\text { Peak No. } \\ \text { of } \\ \text { Species }\end{array} & \begin{array}{l}\text { Peak } \\ \text { Flight } \\ \text { Period } \\ \text { mid-June }\end{array} & \begin{array}{c}\text { Approximate } \\ \text { Elevation (m) }\end{array} \\ \begin{array}{l}\text { Calgary } \\ \text { Banff National }\end{array} & 200 & 45 & 46 \text { to } 1,067 \\ \quad \begin{array}{l}\text { Park } \\ \text { Kananaskis }\end{array} & 165 & 46 & \text { mid-July } & 1,341 \text { and up } \\ \quad \text { Provincial Park } & 122 & .34 & \begin{array}{l}\text { late July } \\ \text { early August }\end{array} & \begin{array}{l}1,615 \text { and up } \\ 2,438\end{array}\end{array}$

must be an important factor in butterfly ecology. A recent literature review of butterfly ecology by Gilbert and Singer 8 indicates that this concept has not been explored by lepidopterists. In Kananaskis Provincial Park, forest fires are especially important in creating the sunny, open habitats which support the greatest variety and most concentrated populations of butterflies. Fire also depresses treeline for a substantial time, thus providing additional alpine habitat for a number of species.

Other major influences on the park butterfly fauna are beaver activity, groundwater discharge, colluvial action, snow avalanches. All these factors, singly or in conjunction with fire provide a variety of non-forest habitats. With the exception of increased water levels in the Kananaskis Lakes, man has had relatively little widespread influence on the butterfly fauna. Linear clearings that result from powerline right-of-ways, trails, and old roads are actually superior places to observe butterflies since the insects apparently treat them as natural openings in the forest canopy.

In general, the park is poor butterfly habitat, similar to the situation reported by Tilden and Huntzinger20 for Crater Lake National Park. Much of the park supports habitats foreign to good butterfly populations and variety: extensive coniferous forest with low plant species diversity and cool, moist microclimate; rock barrens; water; glaciers; and perennial snowbanks. Certain alpine areas such as Highwood Pass support relatively rich butterfly populations. At lower elevations, the most productive habitats are open meadows, shrublands, and sparsely treed to non-treed wetlands.

1BIRD, C. D. 1975a. A calendar of butterflies and skippers of the alpine area of Plateau Mountain. Alberta Naturalist 5:26-28.

2BIRD, C. D. 1975b. A calendar of the skippers and butterflies of Banff National Park. Alberta Naturalist 5:7175.

3BIRD, C. D. 1975c. A revised calender of the butterflies and skippers of Calgary. Calgary Field Naturalist 6:312-314.

${ }^{4} B I R D, C$. D. 1976 . Rhopalocera in the N. B. Sanson Collection. Journal of the Lepidoperists' Society 30:201-206.

5BIRD, C. D. 1977. The lichens, bryophytes, and butterflies of the proposed park in the Kananaskis Lakes area. Unpublished report for Parks Planning and Design Branch; Alberta Recreation, Parks and Widlife. $76 \mathrm{pp}$.

6 EMMEL, T. C. 1964. The ecology and distribution of butterflies in a montane community near Florissant, 
Colorado. American Midland Naturalist 72:358-73.

7EMMEL, T. C. and J. F. EMMEL. 1962. Ecological studies of Rhopalocera in a high Sierran community - Donner Pass, California. I. Butterfly associations and distributional factors. Journal of the Lepidopterists' Society 16:23-44.

8GILBERT L. E. and M. C. SINGER. 1975. Butterfly ecology. Annual Review of Ecology and Systematics 6:365-397.

9HABECK, J. R. and R. W. MUTCH. 1973. Fire dependent forests in the northern Rocky Mountains. Journal of Quaternary Research 3:408-424.

10JAQUES, D. 1977. A preliminary checklist of vascular plants in the Kananaskis Lakes Provincial Park with special reference to rare or disjunct species and plant associations. Unpublished report for Parks Planning and Design Branch, Alberta Recreation, Parks and Wildlife. 59 pp.

${ }^{1}$ KOHLER, S. 1977. Revision of North American Boloria selene (Nymphalidae) with description of a new subspecies. Journal of the Lepidopterists' Society 31:243-268.

2KONDLA, N. G. 1978. An overview vegetation survey of Kananaskis Provincial Park. Unpublished report for Parks Planning and Design Branch; Alberta Recreation, Parks and Wildlife. $123 \mathrm{pp}$.

3MacKENZIE, G. A. 1973. The fire ecology of the forests of Waterton Lakes National Park. M.Sc. Thesis, University of Calgary. 199 pp.

4MILUS TRESS BARRON LTD. 1976. Geology, soils, surficial deposits, and landform inventory and mapping: Kananaskis Provincial Park. Unpublished report for Parks Planning and Design Branch; Alberta Recreation, Parks and Wildlife. 162 pp.

OPLER, P. A. and R. L. LANGSTON. 1968. A distributional analysis of the butterflies of Contra Costa County, California. Journal of the Lepidopterists' Society 22:89-107.
16PEREGRINE RESEARCH AND DOCUMENTATION LTD. 1977. Report on the vertebrate fauna of Kananaskis Provincial Park Unpublished report for Parks Planning and Design Branch; Alberta Recreation Parks and Wildlife. (Volume 1-322 pp, Volume 2-405 pp).

17PIKE, E. M. 1978. Origin of tundra butterflies in Alberta, Canada and their significance in the study of refugia of Wisconsin age. M.Sc. Thesis, University of Alberta. 137 pp.

18SHEPARD, J. H. 1975. Genus Boloria Reuss. Pp. 243-252 in Howe, W. H. (ed.) The butterflies of North America. Doubleday and Co., Inc., Garden City, New York.

19TANDE, G. F. 1977. A fire history of the coniferous forests around Jasper townsite, Jasper National Park, Alberta. M.Sc. Thesis, University of Alberta. 169 pp

20TILDEN, J. W. and D. H. HUNTZINGER. 1977. The butterflies of Crater Lake National Park, Oregon. Journal of Research on the Lepidoptera 16:176192.

21TROTTIER, G. C. 1972. Ecology of the alpine vegetation of Highwood Pass Alberta. M.Sc. Thesis, University of Calgary. 229 pp.

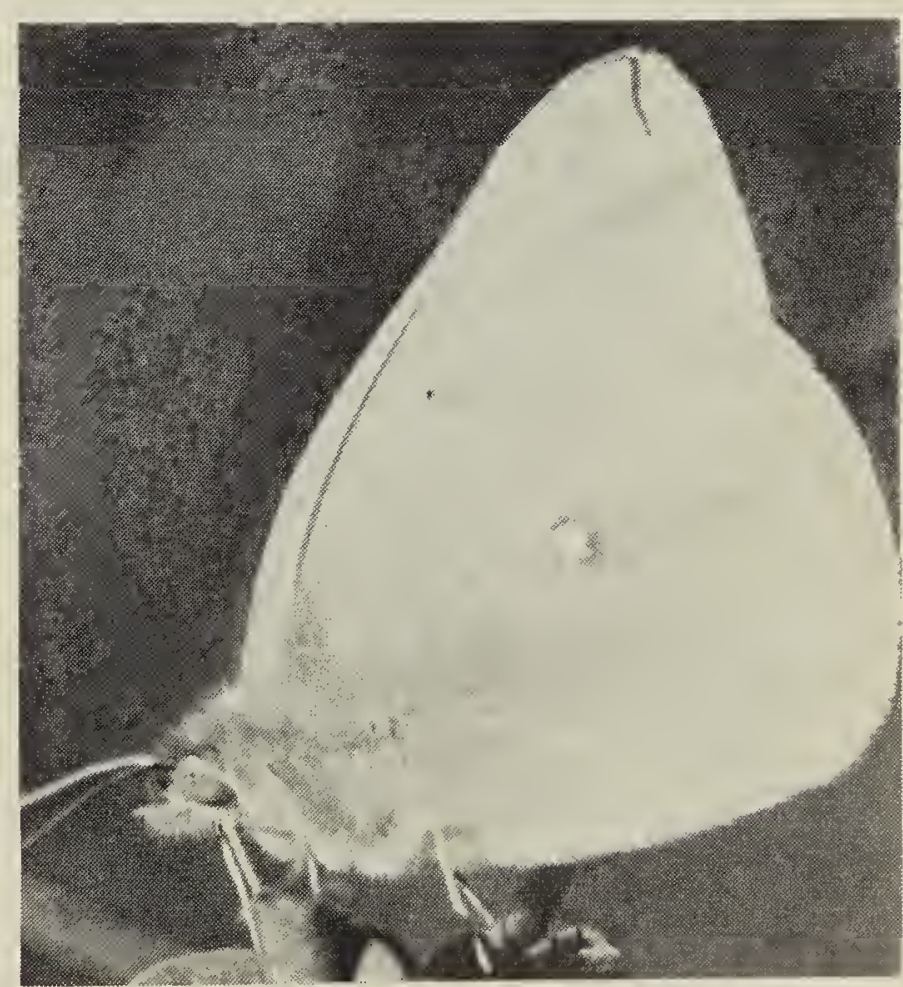

Alexandra Sulphur

C. R. Wershler 